REVIEW

\title{
Influence of hip dysplasia on the development of osteoarthritis of the hip
}

\section{A M Lievense, S M A Bierma-Zeinstra, A P Verhagen, J A N Verhaar, B W Koes}

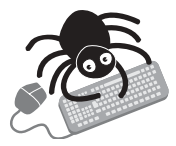

Ann Rheum Dis 2004;63:621-626. doi: 10.1136/ard.2003.009860

Appendix $\mathrm{W} 1$ is available at hittp://www. annrheumdis.com/ supplemental

\begin{abstract}
Background: It has been suggested that in some patients with primary hip osteoarthritis (OA), the disease occurs as a consequence of acetabular dysplasia or hip dysplasia (HD).

Objective: To carry out a systematic review to investigate the association between acetabular dysplasia and hip OA.

Methods: A database search of Medline, Embase, and the Cochrane library was carried out, and articles that aimed at studying the relationship between HD and hip OA were identified. The methodological quality of the selected studies was assessed using a standardised set of criteria, and a best evidence synthesis was used to summarise the results from the individual studies.

Results: Five cohort studies and four case-control studies were included in this review. One cohort study had the correct design to answer the question and was considered to be a high quality study. This study reported a positive association between HD and hip OA. Overall, limited evidence was found for a positive association between HD and hip OA. Most studies included older people. In younger age groups the relation between HD and OA or hip complaints may be much higher.

Conclusion: The evidence for the influence of HD on the occurrence of hip OA, at age 50-60 or older, is limited.
\end{abstract}

See end of article for authors' affiliations

Correspondence to:

Mrs A Lievense, Erasmus

MC, Department of

General Practice, Room

WK 131, Post Box 1738

3000 DR Rotterdam, The

Netherlands; a.lievense@

erasmusmc.nl

Accepted

13 November 2003

O steoarthritis of the hip (hip OA) is an increasing problem in Western societies, and is a major cause of morbidity and disability, especially among the elderly. In addition to the pain and discomfort it causes, OA has major economic consequences. ${ }^{1}$

The reported prevalence of hip OA varies widely owing to differences in the definition of OA or the selection of the study group. Studies in Europe have estimated that about 7$25 \%$ of white people over the age of 55 have hip OA. The prevalence of hip OA appears to be lowest in Asians, followed by African black and native American populations, and is highest in white Europeans. ${ }^{2-5}$

It has been suggested that in some patients with primary hip OA, the disease occurs as a consequence of acetabular dysplasia or hip dysplasia (HD), which persists into adult life. Some radiological observations in patients with hip OA, and follow up studies of subjects with HD support this theory. ${ }^{6-8}$ However, not all studies have reported a positive association. ${ }^{9}$

To investigate if HD pre-dates hip OA, we performed a systematic review, using modern methods for systematically identifying and assessing the available studies.

\section{METHODS}

\section{Identification and selection of the literature}

Relevant publications were searched using the Cochrane library (1993-April 2000), Medline (1966-April 2000), and Embase (1980-April 2000) databases. The following keywords were used: (hip and (arthritis or arthrosis or osteoarthritis or osteoarthrosis) or coxarthrosis) and (risk factor or causative or determinants or predictor or aetiology) and (case-control or retrospective or prospective or longitudinal or follow up or cohort). (A detailed list can be obtained from the corresponding author.) We extended the search by screening the reference lists of all relevant articles identified.

A study was eligible for inclusion if it fulfilled all of the following criteria: (a) one of the aims of the study was to investigate an association between HD and hip OA; $(b)$ the articles were written in English, Dutch, German, French, Danish, Norwegian, or Swedish; (c) the article was a full text article; $(d)$ the patients in the studies had radiological and/or clinical hip OA, a (total) hip replacement, or were on the waiting list for one; and (e) the study design was a cohort or a case-control study.

A study was excluded if the studied population had a specific underlying pathology, such as trauma (fractures), infection, rheumatoid arthritis, ankylosing spondylitis, Perthes' disease, tuberculosis, haemochromatosis, sickle cell disease, Cushing's disease, or femoral head necrosis.

\section{Methodological quality assessment}

The variation of the methodological quality of observational studies may influence the results and conclusions of a systematic review. Therefore, the quality of each study included was assessed by the following procedure.

Two reviewers independently scored the quality of the selected papers according to a standardised set of criteria (table 1). These criteria have been used in previous reviews of observational studies in the field of musculoskeletal disorders and were modified to cover the topic of our review. ${ }^{10-13}$ The criteria concern both the internal validity and the informativeness of the study. Only items reflecting the internal validity of the studies were used to assess the methodological

Abbreviations: $A D$, acetabular depth; $C E$, centre-edge; $H D$, hip dysplasia; IVU, intravenous urography; OA, osteoarthritis 
Table 1 List of criteria for the assessment of the methodological quality of cohort and case-control designed studies

\begin{tabular}{|c|c|c|c|}
\hline Item & Criteria & $\mathrm{V} / \mathrm{I}^{*}$ & $\mathrm{CH} / \mathrm{CC} \dagger$ \\
\hline & Study group & & \\
\hline 1 & Selection before disease was present or at uniform point & V & $\mathrm{CH} / \mathrm{CC}$ \\
\hline 2 & Cases and controls were drawn from the same population & V & $\mathrm{CC}$ \\
\hline 3 & Participation rate $\geqslant 80 \%$ for cases $/$ cohort & $\mathrm{V}$ & $\mathrm{CH} / \mathrm{CC}$ \\
\hline 4 & Participation rate $\geqslant 80 \%$ for controls & $\mathrm{V}$ & $\mathrm{CC}$ \\
\hline \multirow[t]{2}{*}{5} & Sufficient description of baseline characteristics & 1 & $\mathrm{CH} / \mathrm{CC}$ \\
\hline & Assessment of risk factor & & \\
\hline 6 & Exposure assessment was "blinded" & V & $\mathrm{CH} / \mathrm{CC}$ \\
\hline 7 & Exposure was measured identically in study group & V & $\mathrm{CC}$ \\
\hline \multirow[t]{2}{*}{8} & Exposure was assessed before the outcome & V & $\mathrm{CH} / \mathrm{CC}$ \\
\hline & Assessment of hip OA & & \\
\hline 9 & Hip OA was assessed identically in study group & V & $\mathrm{CH} / \mathrm{CC}$ \\
\hline 10 & Presence of hip OA was assessed reproducibly & $\mathrm{V}$ & $\mathrm{CH} / \mathrm{CC}$ \\
\hline 11 & Presence of hip OA was according to valid definitions & V & $\mathrm{CH} / \mathrm{CC}$ \\
\hline \multirow[t]{2}{*}{12} & Classification was standardised & 1 & $\mathrm{CH} / \mathrm{CC}$ \\
\hline & Study design & & \\
\hline 13 & Prospective design was used & V & $\mathrm{CH} / \mathrm{CC}$ \\
\hline 14 & Follow up time $\geqslant 3$ years & V & $\mathrm{CH}$ \\
\hline 15 & Withdrawals $\leqslant 20 \%$ & V & $\mathrm{CH}$ \\
\hline \multirow[t]{2}{*}{16} & Information about completers $v$ withdrawals & i & $\mathrm{CH}$ \\
\hline & Analysis and data presentation & & \\
\hline 17 & Frequencies of most important outcomes were given & I & $\mathrm{CH} / \mathrm{CC}$ \\
\hline 18 & Appropriate analysis techniques were used & V & $\mathrm{CH} / \mathrm{CC}$ \\
\hline 19 & Adjusted for at least age and sex & V & $\mathrm{CH} / \mathrm{CC}$ \\
\hline
\end{tabular}

quality (table 1 and appendix Wl, available at http:// www.annrheumdis.com/supplemental).

In cases of disagreement, both reviewers tried to achieve consensus; if disagreements were not resolved, a third reviewer was consulted to achieve a final judgment.

Several items are not applicable to a certain type of study design (for example, cohort study or case-control study), and therefore do not contribute to the total score of that particular study. This means that the maximum score of each study $(=100 \%)$ was based only on the items applicable to that particular type of study design. Positive scores were summed to give an overall internal validity score.

\section{Best evidence synthesis}

Because the study population, methodological quality and determinants, and outcome measures for hip OA are heterogeneous in observational studies, we refrained from statistically pooling the data, ${ }^{14}$ and performed a "best evidence synthesis". ${ }^{10}{ }^{11} 14-17$

The studies were stratified according to the type of study design. To clarify the question whether HD pre-dates hip OA, the only studies which can really answer this question are prospective cohort studies: that is they follow up patients without hip OA with the presence or absence of HD measured, forward in time, and identify who develops hip OA subsequently. Therefore these studies were judged to have the most valid design. Studies with cross sectional data on hip OA and HD were not considered in the best evidence synthesis.

Furthermore, the studies were ranked according to their methodological quality score ${ }^{10}{ }^{11} 18$ :

- Strong evidence is provided by generally consistent findings in multiple high quality cohort studies

- Moderate evidence is provided by generally consistent findings
- In one high quality cohort study and two or more high quality case-control studies

- In three or more high quality case-control studies

- Limited evidence is provided by (generally consistent) findings

- In a single cohort study

- In $\leqslant 2$ case-control studies

- Conflicting evidence is provided by conflicting findings (that is, $<75 \%$ of the studies reported consistent findings)

- No evidence is provided when no studies can be found.

A study was considered to be of high quality if the methodological quality score was $>60 \%$.

\section{Data extraction}

Two researchers (AML and SMABZ) independently collected the characteristics of the included studies. They collected items concerning the definition of the studied population, how the presence or absence of hip OA was assessed, the assessment of $\mathrm{HD}$, if the study corrected for potentially confounding factors, and which results were reported.

\section{RESULTS}

\section{Identification and selection of the literature}

A total of 2921 references were identified. After an initial examination of the title and the abstract of the references, the full text of papers were screened to determine whether they met our selection criteria. Of these, 12 articles met the criteria. $^{6}{ }^{19-28}$ After screening the reference lists of the selected studies, one other study was included. ${ }^{8}$ For three studies, more than one publication reported different aspects of the studies. ${ }^{6}{ }^{19-22} 28$ All publications were used to extract data about the methods used and the results. Finally, nine studies were included in this review. 
Table 2 Details of the studies included in this review

\begin{tabular}{|c|c|c|c|c|c|}
\hline Author & Definition cases/controls & Definition hip OA & Definition dysplasia & Results & $\begin{array}{l}\text { Quality } \\
\text { score (\%) }\end{array}$ \\
\hline $\begin{array}{l}\text { Cohort } \\
\text { Lane }^{622}\end{array}$ & $\begin{array}{l}\text { White women in four regions of the } \\
\text { USA with (K\&LL } 2-4) \text { and without } \\
\text { (K\&L O) hip OA }(n=58 / 118, \geq 65 \\
\text { years). Nested case-control with } 8.3 \\
\text { (7.4-10.4) years' prospective } \\
\text { follow up }\end{array}$ & $x$ Ray (K\&L) & $\begin{array}{l}\text { CE angle }<30^{\circ} \text {, } \\
A D<9 \mathrm{~mm}\end{array}$ & $\begin{array}{l}\text { Female with } v \text { without hip } \mathrm{OA} \text { had: } \\
\text { A smaller } \mathrm{CE} \text { angle } \mathrm{OR}=3.3 \\
(1.1-10.1) \\
\text { A smaller } \mathrm{AD} O \mathrm{OR}=0.6(0.1-3.3) \\
\text { Dysplasia } \mathrm{OR}=2.8(1.0-7.9)\end{array}$ & 75 \\
\hline Murphy ${ }^{25}$ & $\begin{array}{l}\text { Patients after THR because of hip } \\
\text { OA, with (K\&L } 3-4) \text { and without } \\
(K \& L \text { L }-2) \text { contralateral hip OA } \\
\text { ( } n=74 / 43, \geq 65 \text { years). Nested } \\
\text { case-control with prospective } \\
\text { follow up }\end{array}$ & $x$ Ray (K\&L) & $\begin{array}{l}C E \text { angle, } A D \\
\text { index (depth/width) }\end{array}$ & $\begin{array}{l}\text { CE angle and acetabular index } \\
\text { were significantly smaller in the } \\
\text { patients with } O A(p<0.0001)\end{array}$ & 58 \\
\hline Hasegawa 2021 & $\begin{array}{l}\text { Japanese patients with pre or early } \\
\text { hip OA ( } n=64,13-62 \text { years). } \\
\text { Prospective follow up } 12.8 \text { (10-25) } \\
\text { years }\end{array}$ & $\begin{array}{l}x \text { Ray } \\
\text { (JSN, sclerosis) }\end{array}$ & $\begin{array}{l}\mathrm{CE} \text { angle, } \mathrm{AD} \\
\text { ratio }\end{array}$ & $\begin{array}{l}\text { Patients with a fast progression } \\
\text { from pre to early hip } O A \text { had a } \\
\text { significantly smaller } C E \text { angle, } \\
\text { and a smaller } A D \text { ratio }(p<0.001)\end{array}$ & 50 \\
\hline $\begin{array}{l}\text { Yoshimura } \\
\text { Croff }^{19} \text { Smith }^{9}\end{array}$ & $\begin{array}{l}\text { British patients after IV urography } \\
\text { ( } \mathrm{n}=1498,60-75 \text { years) and } \\
\text { Japanese people after pelvic } x \text { ray } \\
\text { ( } \mathrm{n}=198,60-79 \text { years). Cross } \\
\text { sectional }\end{array}$ & $x$ Ray (MJS) & $C E$ angle, $A D$ & $\begin{array}{l}\text { Correlation between MJS and CE angle: } \\
\text { British male } r=-0.37 \text {, British female } \\
r=-0.25 \text {, Japanese male } r=-0.39 \text {, } \\
\text { Japanese female } r=-0.26\end{array}$ & 50 \\
\hline & & & & $\begin{array}{l}\text { Correlation between MS and AD: } \\
\text { British male } r=-0.15 \text {, British female } \\
r=-0.11 \text {, Japanese male } r=-0.09 \text {, } \\
\text { Japanese female } r=-0.07\end{array}$ & \\
\hline $\operatorname{Lav}^{23}$ & $\begin{array}{l}\text { Male Chinese and British* patients } \\
\text { after IV urography }(\mathrm{n}=999,60-75 \\
\text { years). Cross sectional }\end{array}$ & $x$ Ray (MJS $\leqslant 1.5$ ) & $\begin{array}{l}\mathrm{CE} \text { angle }<25^{\circ} \text {, } \\
\mathrm{AD}<9 \mathrm{~mm}\end{array}$ & $\begin{array}{l}\text { People with an MSS } \leqslant 1.5 v>4 \mathrm{~mm} \\
\text { had a smaller } A D(O R=0.4 \\
(0.05-2.9)) \text { and a smaller CE angle } \\
(O R=0.5(0.03-8.7))\end{array}$ & 42 \\
\hline $\begin{array}{l}\text { Case-control } \\
\text { Laforgia }^{24}\end{array}$ & $\begin{array}{l}\text { Patients in Italy on waiting list for } \\
\text { osteotomy or THR ( } n=60 \text {, average } \\
\text { age } 77 \text { years). Cross sectional }\end{array}$ & Waiting list & CE angle & $\begin{array}{l}\text { CE angle is significantly smaller in } \\
\text { superolateral OA, and significantly } \\
\text { higher in concentral/medial OA } \\
\text { than in controls }\end{array}$ & 38 \\
\hline Murray $^{8}$ & $\begin{array}{l}\text { British patients with hip OA }(n=50) \text {. } \\
\text { Cross sectional }\end{array}$ & $\begin{array}{l}\text { Clinical (patients) x ray } \\
\text { (JSN, cysts, osteophytes, } \\
\text { subluxation) }\end{array}$ & $\begin{array}{l}\text { CE angle }<25^{\circ} \\
A D<9 \mathrm{~mm} \text {. }\end{array}$ & $\begin{array}{l}\text { Patients with HD showed an earlier } \\
\text { age of onset of hip OA ( } 50.8 \text { years } \\
\text { v } 57.7 \text { years in control) }\end{array}$ & 38 \\
\hline Terjesen $^{26}$ & $\begin{array}{l}\text { Patients in Norway at orthopaedic } \\
\text { clinics with hip complaints, with } \\
C E \geqslant 20^{\circ}(n=50,48-81 \text { years). } \\
\text { Cross sectional }\end{array}$ & $\begin{array}{l}\text { Clinical (pain, functional } \\
\text { disability). } x \text { Ray } \\
\text { examination }\end{array}$ & CE angle $<25^{\circ}$ & $\begin{array}{l}\text { No significant difference in CE angle } \\
\text { between patients with } v \text { without hip } \\
\text { OA }\end{array}$ & 31 \\
\hline Wedge $^{27}$ & $\begin{array}{l}\text { Patients in Canada with primary hip } \\
\mathrm{OA}(\mathrm{n}=30,65 \text { years). Retrospective }\end{array}$ & $\begin{array}{l}\text { Clinical (patients). } x \text { Ray } \\
\text { examination }\end{array}$ & $\begin{array}{l}C E \text { angle }<25^{\circ} \text {, } \\
A D<14 \mathrm{~mm} \text { on } \\
A P \times \text { ray examination }\end{array}$ & $\begin{array}{l}\text { Patients with hip } O A \text { had a significantly } \\
\text { smaller } C E \text { angle and } A D\end{array}$ & 23 \\
\hline
\end{tabular}

*From same population as that described by Yoshimura et al. ${ }^{28}$

$A D$, acetabular depth; CE angle, centre-edge angle; IV, intravenous; JSN, joint space narrowing; K\&L, Kellgren and Lawrence; MJS, mean joint space width; OA, osteoarthritis; THR, total hip replacement.

\section{Description of the studies included}

Table 2 gives the characteristics of the included studies.

Five studies had a cohort design. ${ }^{6} 20232528$ After screening the reference lists of the selected studies, one other study was included. ${ }^{8}$ For three studies, more than one publication reported different aspects of the studies ${ }^{9^{19-22} 28}$ and four studies had a case-control design. ${ }^{8} 242627$

Three of the five cohort studies collected the data in a prospective manner, ${ }^{6025}$ and only one study followed up patients without hip OA forward in time. ${ }^{6}$

One study included only men, ${ }^{23}$ and one other only women. ${ }^{6}$ Six studies included patients aged $60-65$ or older, ${ }^{63-2527} 28$ and the other three included a population with younger patients as well. ${ }^{8} 26$ Data on congenital HD were lacking. Three studies reported data on Asian, ${ }^{20}$ or on Asian and white populations. ${ }^{23}{ }^{28}$ All others reported on white people.

Only one study was community based, ${ }^{6}$ all others were hospital based. Of these hospital based studies, two selected the patients not on the presence or absence of hip OA, but according to whether they had had an intravenous urography (IVU). ${ }^{23} 28$
In all studies, HD was assessed by measuring the centreedge (CE) angle - that is, the angle between ( $a$ ) a vertical line drawn from the centre of the femoral head at right angles to the line joining the two femoral head centres, and $(b)$ a line from the centre of the femoral head to the lateral edge of the acetabular roof. Seven of the nine studies also measured the acetabular depth $(\mathrm{AD}$; the perpendicular distance from the deepest point of the acetabular roof to the line joining the lateral margin of the acetabular roof and the upper corner of the symphysis pubis on the same side), index, or ratio. ${ }^{682023252728}$ The cut off point for the definition of HD according to the CE angle was $\leqslant 25^{\circ}$ in three studies ${ }^{62327}$ and $\leqslant 30^{\circ}$ in one study..$^{6}$ One study used a CE angle $\leqslant 20^{\circ}$ as an exclusion criterion for the studied patients. ${ }^{26}$

Two of the five cohort studies defined the presence of hip OA by a radiographic scoring system, described by Kellgren and Lawrence. ${ }^{62}$ In the three other cohort studies the assessment of hip OA was based on the measurements of the joint space width. The four case-control studies based their case series on hospital patients with hip OA, so their definition of hip OA was a combination of clinical signs or complaints and radiographic abnormalities. ${ }^{8242627}$ 


\section{Results of the studies included}

The included studies presented their results in various ways: one reported a correlation coefficient, ${ }^{28}$ and two reported an odds ratio. ${ }^{623}$ The six other studies described the outcomes in global terms only. ${ }^{80} 24-27$

To provide a global overview of the reported outcomes we assessed whether the relationship between HD and the occurrence of hip OA was "positive" (the presence of HD is a risk factor for hip OA), "negative" (HD protects for hip OA), or "no" (there is no (significant) relation). Table 2 gives a more detailed description of the outcomes.

Six studies reported a positive association, ${ }^{6} 820242527$ five of them reported the outcomes in global terms, and the only prospective follow up study reported that patients with dysplasia had a 2.8 higher risk of developing hip OA. ${ }^{6}$ Two studies reported a negative association ${ }^{23}{ }^{28}$; one reported a correlation coefficient of approximately -0.38 implying that a smaller CE angle is correlated with a broader mean joint space. ${ }^{28}$ The other study reported that people with dysplasia had a 0.5 to 0.4 smaller risk of having a hip OA. ${ }^{23}$ Both studies reported partially on the same population. Only one study reported no relationship. ${ }^{26}$

\section{Methodological quality assessment}

The two reviewers scored 514 items and agreed on 467 items $(95 \%, \kappa=0.80)$. The 47 disagreements were resolved at a single consensus meeting. Table 3 shows the studies in order of their methodological quality score, subdivided into the different types of study design (that is cohort and casecontrol studies).

The scores ranged from $75 \%$ to $23 \%$, and the average rating was $45 \%$.

\section{Best evidence synthesis}

Only one of the three prospective cohort studies had a design that really could answer the research question, and this study reached the level of high quality. The other two prospective cohort studies did not reach the level of high quality.

The high quality prospective cohort study reported a positive association between HD and the occurrence of hip OA with prospective data, implying that a patient with HD, has a higher chance of getting hip OA. This means that there is limited evidence for a positive association between HD and the development of hip OA.

\section{DISCUSSION}

In this systematic review we summarised the available reported evidence on the influence of HD on the development of hip OA. We may conclude, based on the evidence, that there is limited evidence for a positive association between HD and hip OA. However, most studies included older people (for example, 50-60 years or older). In younger age groups the relation between HD and OA or hip complaints seems to be much higher. ${ }^{29}$ In these kind of populations, however, it is difficult to study the relationship, because the power of a prospective cohort study to estimate an effect in this rare disease would require implausibly large samples.

Five of nine studies had cross sectional data. One of the most important biases in these studies is that the measurements of HD can be modified by the OA process. For example, osteophyte formation might make it difficult to correctly locate the lateral acetabular margin, resulting in less reliable measurements of the $\mathrm{CE}$ angle and $\mathrm{AD}$. Moreover, medial migration of the femoral head may increase the CE angle.

In fact, the data we found support the theory that changes in the hip joint geometry as a result of OA may be responsible for the (weak) negative association. All three prospective studies, including the only study with a population without hip OA at the beginning of the study, reported a positive

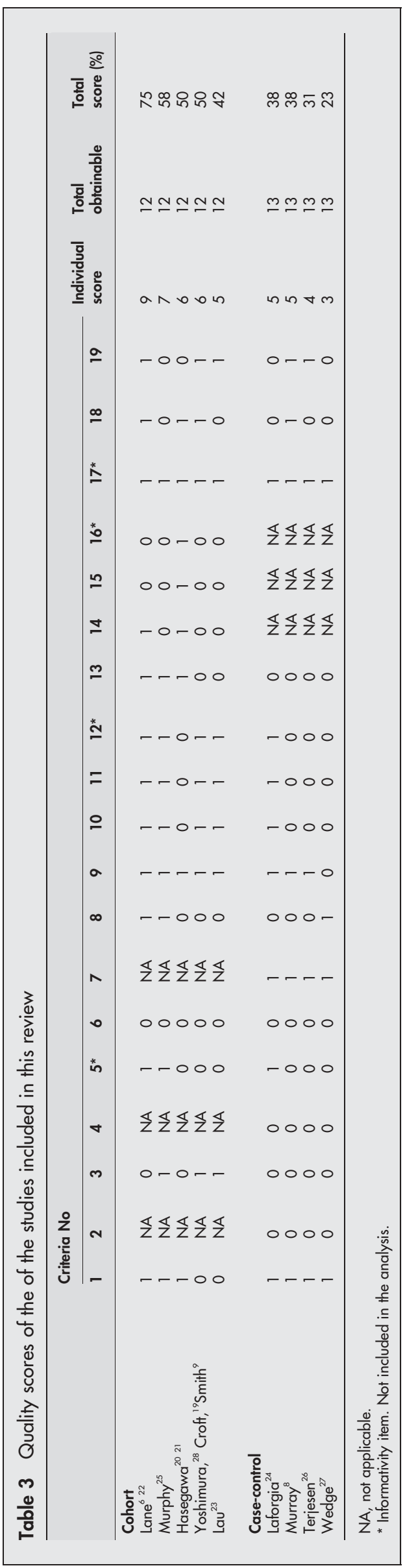


relationship between HD and the occurrence of hip OA, and the single retrospective study reported no association.

Two of the five cohort studies included people who had had an IVU. Although these populations are hospital based, the requirement for an IVU implies no marked differences in acetabular dimensions, and therefore biases due to selection for treatment of hip OA, are avoided. However, the leg position during $x$ ray examination is not standardised for an IVU, and patients with sustained hip OA tend to lie with the leg in external rotation. This rotation of the hip may influence the measurements of the CE angle. Although these differences are estimated to be small, ${ }^{30}$ they may produce less reliable results. Both studies performed with data from IVU reported a negative association, whereas five of the seven other studies reported a positive association, and none reported a negative association. Also the difference in the $x$ ray techniques used (for example, for trauma, IVU, and before hip replacement) might make it more difficult to compare the data.

Besides restrictions of the included studies, this review may also have several restrictions.

\section{Identification and selection of the literature}

Although we put much effort into identifying all relevant articles, our literature search may have some limitations, not only because some relevant articles might have been missed because they used other keywords or had unclear abstracts but also because not all published articles are indexed in databases. Additionally, we excluded articles written in languages other than English, Dutch, German, French, Danish, Norwegian, or Swedish.

To investigate the amount of potential publication bias for our study, we planned to make a funnel plot, ${ }^{10}$ but only three of the nine studies provided enough data to allow us to make such a plot. Unfortunately, this means that we are unable to visualise the possibility of publication bias in this review.

\section{Quality assessment and best evidence synthesis}

The quality assessment was challenging because no previously tested and validated criteria lists for observational studies in the field of OA have been published. In addition, limited data were found on performing a best evidence synthesis with observational studies (in contrast with randomised controlled trials). ${ }^{31}$ We therefore presented our methods in a reproducible manner, in order to give the reader insight into the way in which our level of evidence was reached.

In the best evidence synthesis we defined the criteria so that only prospective cohort studies are able to address the research question. In fact, only those with a disease-free population at the beginning of the study are able to do that, but because populations with early hip OA that were studied prospectively can support the evidence, we included them as well. We are however cautious about this kind of information because of the bias that can be introduced. (Acetabular deformity can pre-date hip OA.)

\section{Explanations for the results}

Despite the above mentioned biases and limitations, the evidence for an association between HD and the development of hip OA is limited. A hypothetical mechanism to explain the association is the increased joint stress due to decreased joint surface area (smaller CE angle) or joint incongruity (smaller AD)..$^{32} 33$

In view of the limited evidence on the positive relationship between mild forms of HD and the occurrence of hip OA in the elderly, and the lack of information in younger patients, more well designed prospective population based studies are needed in order to provide more precise and valid information on this relation.

\section{ACKNOWLEDGEMENTS}

This study was supported by a grant from the Dutch Arthritis Association.

\section{Authors' affiliations}

A M Lievense, S M A Bierma-Zeinstra, A P Verhagen, B W Koes, Department of General Practice, Erasmus MC, Rotterdam, the Netherlands

J A N Verhaar, Department of Orthopaedics, Erasmus MC, Rotterdam, the Netherlands

\section{REFERENCES}

1 Hadler NM. Osteoarthritis as a public health problem. Clin Rheum Dis 1985; 11:175-85

2 Felson DT, Zhang Y. An update on the epidemiology of knee and hip osteoarthritis with a view to prevention. Arthritis Rheum 1998:41:1343-55.

3 Hoaglund FT, Oishi CS, Gialamas GG. Extreme variations in racial rates of total hip arthroplasty for primacy coxarthrosis: a population-based study in San Francisco. Ann Rheum Dis 1995;54:107-10.

4 Tepper S, Hochberg MC. Factors associated with hip osteoarthritis: data from the First National Health and Nutrition Examination Survey (NHANES-I). Am J Epidemiol 1993;137:1081-8.

5 Lawrence RC, Hochberg MC, Kelsey JL, McDuffie FC, Medsger TA Jr, Felts WR, et al. Estimates of the prevalence of selected arthritic and musculoskeletal diseases in the United States. J Rheumatol 1989;16:427-41.

6 Lane NE, Lin P, Christiansen L, Gore LR, Williams EN, Hochberg MC, et al. Association of mild acetabular dysplasia with an increased risk of incident hip osteoarthritis in elderly white women: the study of osteoporotic fractures. Arthritis Rheum 2000;43:400-4.

7 Cooperman D, Wallensten R, Stulberg S. Acetabular dysplasia in the adult. Clin Orthop 1983;175:79-85.

8 Murray RO. The aetiology of primary osteoarthritis of the hip. Br J Radiol 1965;38:810-24.

9 Smith RW, Egger P, Coggon D, Cawley MI, Cooper C. Osteoarthritis of the hip joint and acetabular dysplasia in women. Ann Rheum Dis 1995:54:179-81.

10 Lievense AM, Bierma-Zeinstra SMA, Verhagen AP, Verhaar JAN, Koes BW. Influence of work on the development of osteoarthritis of the hip: a systematic review. J Rheumatol 2001;28:2520-8.

11 Lievense AM, Bierma-Zeinstra SMA, Verhagen AP, Verhaar JAN, Koes BW. Prognostic factors of progress of hip osteoarthritis: a systematic review. Arthritis Care Res 2002; 47:556-62.

12 Borghouts JA, Koes BW, Bouter LM. The clinical course and prognostic factors of non-specific neck pain: a systematic review. Pain 1998;77:1-13.

13 Hoogendoorn WE, van Poppel MN, Bongers PM, Koes BW, Bouter LM. Physical load during work and leisure time as risk factors for back pain. Scand J Work Environ Health 1999;25:387-403.

14 Zeegers MP, Heisterkamp SH, Kostense PJ, van der Windt DA, Scholten RJ. De praktiijk van systematische reviews. VII. Het combineren van de resultaten van observationele onderzoeken. Ned Tijdschr Geneeskd 2000;144:1393-7.

15 van Tulder MW, Assendelft WJ, Koes BW, Bouter LM. Method guidelines for systematic reviews in the Cochrane Collaboration Back Review Group for Spinal Disorders. Spine 1997:22:2323-30.

16 Guyatt GH, Sackett DL, Sinclair JC, Hayward R, Cook DJ, Cook RJ. Users' guides to the medical literature. IX. A method for grading health care recommendations. Evidence-Based Medicine Working Group. JAMA 1995;274: 1800-4.

17 Slavin RE. Best evidence synthesis: an intelligent alternative to meta-analysis. J Clin Epidemiol 1995;48:9-18.

18 Bronfort G. Spinal manipulation: current state of research and its indications. Neurol Clin 1999;17:91-111.

19 Croft P, Cooper C, Wickham C, Coggon D. Osteoarthritis of the hip and acetabular dysplasia. Ann Rheum Dis 1991;50:308-10.

20 Hasegawa Y. Spontanverlauf Der Koxarthrose Bei Dysplastischen Huften. Orthopade 1994;23:185-90.

21 Hasegawa $Y$, Iwata H, Mizuno M, Genda E, Sato S, Miura T. The natural course of osteoarthritis of the hip due to subluxation or acetabular dysplasia. Arch Orthop Trauma Surg 1992;111:187-91.

22 Lane NE, Nevitt MC, Cooper C, Pressman A, Gore R, Hochberg M. Acetabular dysplasia and osteoarthritis of the hip in elderly white women. Ann Rheum Dis 1997:56:627-30.

23 Lau EM, Lin F, Lam D, Silman A, Croft P. Hip osteoarthritis and dysplasia in Chinese men. Ann Rheum Dis 1995;54:965-9

24 Laforgia R, Specchiulli F, Solarino G, Nitti L. Radiographic variables in normal and osteoarthritic hips. Bull Hosp Jt Dis 1996;54:215-21.

25 Murphy SB, Ganz R, Muller ME. The prognosis in untreated dysplasia of the hip. A study of radiographic factors that predict the outcome. J Bone Joint Surg Am 1995;77:985-9.

26 Terjesen T, Benum P, Anda S, Svenningsen S. Increased femoral anteversion and osteoarthritis of the hip joint. Acta Orthop Scand 1982;53:571-5.

27 Wedge JH, Wasylenko MJ, Houston CS. Minor anatomic abnormalities of the hip joint persisting from childhood and their possible relationship to idiopathic osteoarthrosis. Clin Orthop Relat Res 1991;264:122-8. 
28 Yoshimura N, Campbell L, Hashimoto T, Kinoshita H, Okayasu T, Wilman C, et al. Acetabular dysplasia and hip osteoarthritis in Britain and Japan. Br J Rheumatol 1998;37:1193-7.

29 Dudkiewicz I, Salai M, Ganel A, Blankstein A, Chechik A. Total hip arthroplasty in patients younger than 30 years of age following developmental dysplasia of hip (DDH) in infancy. Arch Orthop Trauma Surg 2002;122:139-42.

30 Croft P, Cooper C, Wickham C, Coggon D. Defining osteoarthritis of the hip for epidemiologic studies. Am J Epidemiol 1990;132:514-22.
31 Altman DG. Statistics in medical journals: some recent trends. Stat Med 2000;19:3275-89.

32 Maxian TA, Brown TD, Weinstein SL. Chronic stress tolerance levels for human articular cartilage: two nonuniform contact models applied to longterm follow-up of CDH. J Biomech 1995;28:159-66.

33 Hadley NA, Brown TD, Weinstein SL. The effects of contact pressure elevations and aseptic necrosis on the long-term outcome of congenital hip dislocation. J Orthop Res 1990;8:504-13.

\section{Clinical Evidence-Call for contributors}

Clinical Evidence is a regularly updated evidence based journal available worldwide both as a paper version and on the internet. Clinical Evidence needs to recruit a number of new contributors. Contributors are health care professionals or epidemiologists with experience in evidence based medicine and the ability to write in a concise and structured way.

\section{Currently, we are interested in finding contributors with an interest in the following clinical areas:}

Altitude sickness; Autism; Basal cell carcinoma; Breast feeding; Carbon monoxide poisoning; Cervical cancer; Cystic fibrosis; Ectopic pregnancy; Grief/bereavement; Halitosis; Hodgkins disease; Infectious mononucleosis (glandular fever); Kidney stones; Malignant melanoma (metastatic); Mesothelioma; Myeloma; Ovarian cyst; Pancreatitis (acute); Pancreatitis (chronic); Polymyalgia rheumatica; Post-partum haemorrhage; Pulmonary embolism; Recurrent miscarriage; Repetitive strain injury; Scoliosis; Seasonal affective disorder; Squint; Systemic lupus erythematosus; Testicular cancer; Varicocele; Viral meningitis; Vitiligo However, we are always looking for others, so do not let this list discourage you.

\section{Being a contributor involves:}

- Appraising the results of literature searches (performed by our Information Specialists) to identify high quality evidence for inclusion in the journal.

- Writing to a highly structured template (about 2000-3000 words), using evidence from selected studies, within 6-8 weeks of receiving the literature search results.

- Working with Clinical Evidence Editors to ensure that the text meets rigorous epidemiological and style standards.

- Updating the text every eight months to incorporate new evidence.

- Expanding the topic to include new questions once every 12-18 months.

If you would like to become a contributor for Clinical Evidence or require more information about what this involves please send your contact details and a copy of your CV, clearly stating the clinical area you are interested in, to Claire Folkes (cfolkes@bmigroup.com).

\section{Call for peer reviewers}

Clinical Evidence also needs to recruit a number of new peer reviewers specifically with an interest in the clinical areas stated above, and also others related to general practice. Peer reviewers are health care professionals or epidemiologists with experience in evidence based medicine. As a peer reviewer you would be asked for your views on the clinical relevance, validity, and accessibility of specific topics within the journal, and their usefulness to the intended audience (international generalists and health care professionals, possibly with limited statistical knowledge). Topics are usually 2000-3000 words in length and we would ask you to review between 2-5 topics per year. The peer review process takes place throughout the year, and our turnaround time for each review is ideally 10-14 days.

If you are interested in becoming a peer reviewer for Clinical Evidence, please complete the peer review questionnaire at www.clinicalevidence.com or contact Claire Folkes(cfolkes@bmigroup.com). 